\title{
Acute Toxicity Assay Using Mysid as an Alternative Test Organism in the Assessment of the Aqueous Fraction of Sediment
}

Charrid Resgalla ( $\nabla$ cresgalla@univali.br )

UNIVALI https://orcid.org/0000-0002-4444-3968

Rafaela Silveira

UNIVALI: Universidade do Vale do Itajai

Danielle Vieira

UNIVALI: Universidade do Vale do Itajai

\section{Research Article}

Keywords: Marine ecotoxicology, Mysidopsis juniae, Seawater, Toxicity, Complexation, Bioavailability

Posted Date: April 13th, 2021

DOI: https://doi.org/10.21203/rs.3.rs-398600/v1

License: (1) This work is licensed under a Creative Commons Attribution 4.0 International License.

Read Full License

Version of Record: A version of this preprint was published at Ecotoxicology on September 17th, 2021. See the published version at https://doi.org/10.1007/s10646-021-02482-7. 


\section{Abstract}

The evaluation of sediment quality through biological testing of the aqueous fraction can be applied in dredging situations and is associated with a small number of confounding factors. The use of test organisms that are relatively resistant to contaminants is recommended when working with complex mixtures such as sediments. In this study, the sensitivity of the mysid Mysidopsis juniae to total ammonia and metals was investigated in acute toxicity laboratory tests and the results were compared to those obtained in the traditional test with sea urchin embryos and larvae. The ability of the toxicity identification and evaluation (TIE) technique, with the use of EDTA and sodium thiosulfate, to indicate the factors responsible for adverse effects was determined. The results indicate that mysids are almost 5 times more resistant than the sea urchin to unionized ammonia, more sensitive to $\mathrm{Cd}^{2+}$ and $\mathrm{Ni}^{2+}$ and more resistant to $\mathrm{Zn}^{2+}$ and $\mathrm{Pb}^{2+}$. With the TIE technique and with the use of EDTA as a complexing agent, a greater resolution was observed in the diagnosis of the presence of the metals $\mathrm{Cd}^{2+}$ and $\mathrm{Ni}^{2+}$, which could be applied to the aqueous fraction of the sediment.

\section{Introduction}

Estuarine sediments and semi-closed marine environments such as inlets are today considered as sources of contaminants, especially since they are subject to dredging activities (Manap and Voulvoulis, 2016). However, in ecotoxicological tests carried out to evaluate the quality of sediments, problems with confounding factors, such as unionized ammonia, as well as the use of tests or test organisms of inadequate sensitivity to the environmental matrix under study, are encountered (Lapota et al., 2000).

Considering that they are sources of contaminants, sediments can not theoretically be evaluated using inadequately sensitive test organisms or chronic toxicity tests. In general, environments with predominantly fine (silt and clay) sediments would naturally present a diverse chemical composition, characterizing them as complex mixtures, which are frequently cited in the literature (Heinis et al., 2004, Stojak et al., 2015, Li et al., 2018). This enrichment of fine sediments is directly correlated with human occupation and the associated activities, and estuaries are the most impacted environments in the coastal region.

In Brazil, the CONAMA Resolution 454 (CONAMA, 2012), which establishes guidelines for the evaluation of degraded material and its disposal, does not consider the use of the aqueous fraction of the sediment in the ecotoxicological evaluation. The aqueous fraction is widely used in the interpretation of impacts originating from dredging activities, in addition to allowing greater capacity to eliminate the effects of confounding factors on the test results. Likewise, information on sediment toxicity is not sufficient to provide a basis for decision-making in the area of environmental management (USEPA, 2007), and appropriate techniques, such as toxicity identification and evaluation (TIE), have not been widely applied in the evaluation of sediments in Brazil (Badaró-Pedroso and Rachid, 2002). In addition, the abovementioned resolution does not address dispersion via the plume of sediment associated with the use of Hooper-type vessels or the analysis of local benthic communities. 
Toxicity tests carried out with sediments have a wide range of characteristics and applications, mainly when there is interest in a particular contaminant. Tests with total sediment are the most complete, since they involve the evaluation of the presence of soluble and insoluble contaminants, requiring the use of benthic test organisms. But this type of assay accumulates a greater number of confounding factors, such as unionized ammonia and grain size, which are not normally compatible with the test organisms (Moreira et al., 2019). On the other hand, testing the aqueous fraction of the sediment is more practical and has a lower number of confounding factors (Lapota et al., 2000). This approach is recommended for assessing sediments involved in dredging activities, mainly because a wide range of planktonic test organisms can be used, and it allows an assessment of the sediment plume formed in areas where dredged sediment is discarded.

In this context, as a proposal for routine use in assessing the sediment quality in estuarine port regions, which are subject to continuous maintenance dredging activities and sporadically deepening dredging, this paper reports a comparative study of the sensitivity of mysids in acute toxicity tests in relation to chronic tests with the sea urchin (Resgalla Jr. et al., 2012). The sensitivity of mysids to total ammonia and different metals was compared, and the TIE (USEPA, 1996 and 2007, Ho and Burgess, 2009) was used to allow a more accurate interpretation of the causes of toxicity in these complex mixtures. The results of this study will also be of interest in the evaluation of marine sediment quality, expanding the choice of test organisms available, and the importance of analyzing the aqueous fraction of the sediment is highlighted.

\section{Materials And Methods}

Acute tests were carried out with the mysid (Crustacea) Mysidopsis juniae (Silva, 1979) using the methodology described in the standard NBR/ABNT (2017). The basic procedure involved the cultivation of adult organisms in $10 \mathrm{~L}$ aquariums, fed with enriched Artemia sp naupliu, and juveniles up to 7 days old were used in the tests.

The toxicity tests carried out on the juveniles with EDTA, sodium thiosulfate, ammonium chloride and the different metals were performed in $300 \mathrm{~mL}$ glass beakers, using $200 \mathrm{~mL}$ of test solution and 10 juveniles per test flask. Six concentrations and a control (seawater) were prepared for each test substance, with three replicates. For the metals $\mathrm{Hg}^{2+}, \mathrm{Cd}^{2+}, \mathrm{Ni}^{2+}$ and $\mathrm{Pb}^{2+}$ standard solutions for atomic absorption produced by Merck ${ }^{\circledR}$ were used. For the metals and compounds $\mathrm{Cu}^{2+}, \mathrm{Cr}^{6+}, \mathrm{Zn}^{2+}, \mathrm{EDTA}$, sodium thiosulfate and ammonium chloride, the salts $\mathrm{CuSO}_{4} \cdot 5 \mathrm{H}_{2} \mathrm{O}, \mathrm{K}_{2} \mathrm{Cr}_{2} \mathrm{O}_{7}, \mathrm{ZnSO}_{4} \cdot 7 \mathrm{H}_{2} \mathrm{O}, \mathrm{C}_{10} \mathrm{H}_{14} \mathrm{Na}_{2} \mathrm{O}_{8} .2 \mathrm{H}_{2} \mathrm{O}$, $\mathrm{Na}_{2} \mathrm{~S}_{2} \mathrm{O}_{3} .5 \mathrm{H}_{2} \mathrm{O}$ and $\mathrm{NH}_{4} \mathrm{Cl}$, were used, respectively, purchased from Merck ${ }^{\circledR}$.

After determination of the maximum effective concentration $\left(\mathrm{EC}_{100}\right)$ in the metal sensitivity tests, new tests were carried out with the same metal concentrations in association with EDTA or sodium thiosulfate. The maximum concentrations used were $100 \mathrm{mg} \mathrm{L}^{-1}$ for EDTA and $10 \mathrm{mg} \mathrm{L}^{-1}$ for sodium thiosulfate (based on the results obtained in complexing agent toxicity tests) with a 2-h stabilization period between preparing the solutions and exposure of the juveniles to the test flasks. In these tests, six 
concentrations of each complexing agent and the control (complexing agent without metals) were prepared.

The tests were carried out in an incubator at $25 \pm 2{ }^{\circ} \mathrm{C}$, with a $12 \mathrm{~h}$ light-dark cycle, for $96 \mathrm{~h}$. Every $24 \mathrm{~h}$ the test flasks were examined for the quantification of live juveniles and the removal of dead juveniles, and Artemia sp naupliu was added as food. The test was validated by the percent effect control with less than $10 \%$ (mortality). The salinity and $\mathrm{pH}$ were measured at the start and end of the experiments using a ThermoOrion 162A conductivity meter and a ThermoOrion $370 \mathrm{pH}$ meter, respectively. The salinity and $\mathrm{pH}$ of the tests presented averages of 32.92 (32.35-33.43) and 8.04 (7.99-8.11), respectively. In the test solutions, changes in $\mathrm{pH}$ and salinity were not observed after the addition of EDTA and sodium thiosulfate.

The median lethal concentration values $\left(\mathrm{LC}_{50}\right)$ for the metals (expressed on a salt mass basis, i.e., a salt molar weight basis), EDTA, sodium thiosulfate and ammonium chloride were estimated by the Trimmed Spearman-Karber method, using the TSK program, version 1.5 (EPA, Cincinnati, Ohio), on the basis of the percent effect observed (mortality) in the tests.

For the graphic representation of the tests performed, the original data were analyzed applying the Abbott equation (USEPA, 2002) in order to eliminate the variability between the batches of organisms used for the different assays, based on the effects observed in the control flasks.

\section{Results}

The mysid juveniles of $M$. juniae showed greater sensitivity to sodium thiosulfate compared to EDTA, with $\mathrm{LC}_{50}$ values of $28.5 \mathrm{mg} \mathrm{L}^{-1}( \pm 2.32)$ and $277.02( \pm 6.55)$, respectively. Based on these results, the adopted concentrations of the complexing agents in mixture with metals were $100 \mathrm{mg} \mathrm{L}^{-1}$ for EDTA and $10 \mathrm{mg} \mathrm{L}^{-1}$ for sodium thiosulfate (Fig. 1), ensuring the absence of any effect on mysid juveniles. For ammonium chloride, the test indicated that this organism has a high resistance to ammonia with an $\mathrm{LC}_{50}$ of $63.13 \mathrm{mg} \mathrm{L}^{-1}( \pm 10.82)$ and the concentration of unionized ammonia $\left(\mathrm{NH}_{3}\right.$ - based on the salinity, $\mathrm{pH}$ and temperature of the test solution) with no effect on mortality was $236 \mathrm{mg} \mathrm{L}^{-1}$.

The sensitivity of M. juniae juveniles to the metals tested is shown in Table 1 and Fig. 2. According to the $\mathrm{LC}_{50}$ values generated in this study, the species presented greater sensitivity to $\mathrm{Hg}^{2+}$ and $\mathrm{Cu}^{2+}$ and higher resistance to $\mathrm{Pb}^{2+}$ and $\mathrm{Cr}^{6+}$.

When the tests were performed with lethal concentrations of $\mathrm{LC}_{100}$, representing a $100 \%$ effect of the metals on the organisms, complexed with the addition of different concentrations of EDTA, it was observed that this complexing agent has the capacity to remove the toxicity of $\mathrm{Zn}^{2+}$ and $\mathrm{Cu}^{2+}$ and to a lesser extent of $\mathrm{Pb}^{2+}, \mathrm{Cd}^{2+}$ and $\mathrm{Ni}^{2+}$ (Fig. 3). When sodium thiosulfate was used as a complexing agent, only $\mathrm{Hg}^{2+}$ presented a weak reduction in toxicity (Fig. 4). Thus, the complexation capacity of sodium thiosulfate and its ability to remove toxicity toward M. juniae juveniles was lower compared with EDTA. 
Table 2 shows a summary of the comparison between the results obtained in this study and those published by Resgalla Jr. et al. (2012) for the complexation of metals in tests with the embryo-larva of the sea urchin Arbacia lixula.

\section{Discussion}

A limiting factor in the evaluation of the quality of sediments from ecotoxicological tests is the presence of unionized ammonia $\left(\mathrm{NH}_{3}\right)$, common in sediments with a high content of organic matter. This limitation is associated with the fact that the toxicity of this form of nitrogen could lead to false results when using very sensitive test organisms. Embryos and larvae of sea urchins have a high sensitivity to $\mathrm{NH}_{3}$ in a concentration of $0.050 \mathrm{mg} \mathrm{L}^{-1}$ as a tolerance limit for the development of organisms (NBR/ABNT, 2020 and Máximo et al., 2008). Likewise, sperm used in sea urchin fertilization assays can be twice as resistant to unionized ammonia $\left(\mathrm{LC}_{50}=0.169 \mathrm{mg} \mathrm{L}^{-1}\right)$ (Lee et al., 2013). In the present study, the mysid $M$. juniae showed a higher resistance to unionized ammonia $\left(\mathrm{LC}_{50}\right.$ of $0.595 \mathrm{mg} \mathrm{L}^{-1}$ and NOEC of $0.236 \mathrm{mg} \mathrm{L}^{-}$ ${ }^{1}$ ), indicating that this is a good test organism for the aqueous fraction of the sediment. However, it was found to be less resistant than benthic organisms in trials with total sediment, such as the benthic copepod Nitokra sp $\left(\mathrm{LC}_{50}=1.7 \mathrm{mg} \mathrm{L}^{-1}\right)$ (Souza et al., 2012).

The results obtained in this study showed that the sensitivity of $M$. juniae to different metals varies and ranking based on the 96-h $\mathrm{LC}_{50}$ values showed increasing metal toxicity as follows: chromium < lead < zinc < nickel < cadmium < copper $\approx$ mercury. Studies by Lussier et al. (1985) and Verslycke et al. (2003) with the mysids Mysidopsis bahia and Neomysis integer and by Cherkashin and Blinova (2010) presented a metal toxicity ranking very similar to that observed in this study, mainly for the high and low toxicity extremes. Verslycke et al. (2003), however, noted a strong influence of salinity on the availability of metal ions. Few studies on the sensitivity of $M$. juniae toward metals have been reported, but the results obtained in this work are comparable with those obtained by Figuerêdo et al. (2016), who obtained $\mathrm{LC}_{50}$ values of $0.159 \mathrm{mg} \mathrm{L}^{-1}$ for $\mathrm{Zn}^{2+}$ and $0.059 \mathrm{mg} \mathrm{L}^{-1}$ for $\mathrm{Ni}^{2+}$, that is, greater sensitivity in relation to this study, but in agreement regarding the order of toxicity of the metals.

In relation to the complexation agents, in contrast to a study by Resgalla et al. (2012) on the sea urchin Arbacia lixula, the mysid $M$. juniae showed low tolerance to sodium thiosulfate, with an $\mathrm{LC}_{50}$ of $28.5 \mathrm{mg}$ $\mathrm{L}^{-1}( \pm 2.32)$ but a high resistance to EDTA $\left(\mathrm{LC}_{50}=277.02 \mathrm{mg} \mathrm{L}^{-1} \pm 6.55\right)$. Considering that the USEPA (1996) notes the fundamental importance of metal complexing agents having low toxicity, the efficiency of sodium thiosulfate in removing the toxicity of metals can be considered a limiting factor in its use.

Sodium thiosulfate is used in TIE procedures to remove the toxicity of oxidants such as chlorides, bromides, sulfides and iodides. Thiosulfate can also complex some cationic metals like cadmium, copper, silver and mercury in freshwater tests, due to its anionic property (SAIC, 2003), but the complexation capacity is dependent on the concentration of oxidants in the test solution (USEPA, 1991). Despite the limitation regarding the sodium thiosulfate concentration that can be used, due to the sensitivity of the 
test organism, this reducing agent can be recommended for use in cases of contamination by mercury, as it achieved a 30 to $43 \%$ decrease in the original toxicity for this metal, in agreement with the results Resgalla Jr. et al. (2012) obtained in the tests with sea urchins (Table 2).

In the case of EDTA, the complexation was not only efficient for the metals $\mathrm{Cu}^{2+}$ and $\mathrm{Zn}^{2+}$, as observed by Resgalla Jr. et al. (2012), but also, to a certain extent, for $\mathrm{Cd}^{2+}$ and $\mathrm{Ni}^{2+}$ and $\mathrm{Pb}^{2+}$. These results highlight that the use of mysids presents a diagnostic advantage, being suitable for a greater diversity of metals in relation to sea urchin embryo-larva. Burgess et al. (1996), using phase I of the TIE with marine species, also observed a greater resistance of Mysidopsis bahia to EDTA in relation to sodium thiosulfate as well as the ability of EDTA to reduce $\mathrm{Cu}^{2+}$ toxicity.

The similarity in the complexing capacity of EDTA and sodium thiosulfate when applied in marine tests on M. juniae and the sea urchin Arbacia lixula (Resgalla Jr. et al., 2012) highlights the differences in relation to freshwater tests reported by Burgess et al. (1995) and Hockett and Mount (1996). The complexation capacity of EDTA with regard to bivalent metals in freshwater is around 1:2.3 (metal:EDTA) (SAIC, 2003), while in this study the corresponding ratios were 1:25.0 for $\mathrm{Cu}^{2+}, 1: 3.12$ for $\mathrm{Zn}^{2+}$ and 1:2.50 for $\mathrm{Pb}^{2+}$. EDTA chelation is dependent on the $\mathrm{pH}$ (Holleman and Wiberg, 2001), type of metal, presence of other binders in solution, metal X EDTA affinity and, mainly, the availability of $\mathrm{Ca}^{2+}$ and $\mathrm{Mg}^{2+}$ (USEPA 2007), which can compete for active EDTA sites (Hering and Morel, 1989) in salt water.

In general, sediments from coastal port areas, which are commonly subjected to dredging activities, have high concentrations of metals (Moreira et al., 2017) and there are no reliable protocols for assessing sediment toxicity (Moreira et al., 2019). In the case of tests using the aqueous fraction of the sediment, unionized ammonia is considered a confounding factor, limiting the interpretation of the results (Chapman et al., 2002). This enhances the advantage of the use of mysids in the tests with elutriate compared to the embryo-larva of sea urchins.

In addition, the sensitivity of $M$. juniae to the effects of metals observed in this study is consistent with results reported by Moreira at el. (2019), who classified sediment quality based on assays with this test organism. Their results tend to be closer to those obtained in tests with total sediment (amphipod and benthic copepod) than with the sea urchin embryo for both the sediment-water interface and the elutriate.

Mysids are not exclusively planktonic organisms but also bentho-pelagic and they have a strong association with the bottom and the sediments from coastal environments. They are typical organisms of estuaries (Day, 1989; Blaxter et al., 1980) and dissipative sandy beaches (Brown and Mclachlan, 1990) with trophic importance in these environments. Because of this, the use of mysids to assess sediment quality can be optimized using the sediment-water interface technique (Heijerick et al., 2000) with the advantage of eliminating barriers between the water column and the sediment (e.g., a mesh) in addition to the rapid analysis of surviving organisms in acute tests. Nimmo and Hamaker (1982) noted the direct relationship between the degree of contamination of the sediment and the effect in acute tests on mysids. 
The objective of this study was not to find a substitute for the use of chronic tests of sea urchin embryolarva applied to the aqueous fraction of the sediment. Instead, as highlighted by Burton and Johnston (2010), there is a need for the use of several methods to better characterize the contamination status of sediments. These studies help to identify species sensitive to stressors present in the sediment, through the exposure of various species, as well as to better understand the different matrices, such as the solid and aqueous fractions of the sediments, in addition to considering the connection between the characteristics of an organism and its response to exposure to contaminants.

The results reported herein indicate that the resistance of the mysid Mysidopsis juniae toward unionized ammonia is almost 5 times greater than that of sea urchin embryo-larva. This represents an advantage with regard to its use for assessing the quality of sediments, considering both the aqueous fraction and the sediment-water interface. The mysid was found to be more sensitive to $\mathrm{Cd}^{2+}$ and $\mathrm{Ni}^{2+}$, more resistant to $\mathrm{Zn}^{2+}$ and $\mathrm{Pb}^{2+}$ and with similar sensitivity to $\mathrm{Hg}^{2+}, \mathrm{Cu}^{2+}$ and $\mathrm{Cr}^{6+}$ when compared to the sea urchin Arbacia lixula. These differences verify its potential for application in the use of the TIE technique, with EDTA as a complexing agent, allowing the diagnosis of the presence of the metals $\mathrm{Cd}^{2+}, \mathrm{Ni}^{2+}, \mathrm{Pb}^{2+}, \mathrm{Cu}^{2+}$ and $\mathrm{Zn}^{2+}$ in samples of the aqueous fraction of sediments.

\section{Declarations}

\section{Acknowledgements}

The authors are grateful to the Port Authority of Itajaí for financial support, through the Monitoring Program of the Port Region of the Itajaí-açu River, and to UNIVALI and CNPq for the institutional scientific initiation scholarship program.

Funding - Port Authority of Itajaí for financial support, through the Monitoring Program of the Port Region of the Itajaí-açu River, and to UNIVALI and CNPq for the institutional scientific initiation scholarship program.

Conflicts of interest/Competing interests: no conflict of interest.

Availability of data and material: not applicable.

Code availability: not applicable.

Authors' contributions: Charrid Resgalla Jr. (coordination, interpretation and writing), Rafaela Silveira (laboratory tests), Danielle Vieira (laboratory tests).

Ethics approval: not applied, studies with invertebrates.

Consent to participate: consensus.

Consent for publication: consensus. 


\section{References}

1. Badaró-Pedroso C, Rachid BRF (2002) Capítulo 19 - TIE Técnicas para identificação de agentes tóxicos em amostras líquidas. In: Nascimento IA, Sousa ECPM, Nippe M (eds) Métodos em ecotoxicologia marinha. Aplicações no Brasil. Editora Artes Gráficas e Indústria LTDA, São Paulo, pp 217-232

2. Blaxter JHS, Russell FS, Yonge M (1980) The Biology of Mysids and Euphausiids. Adv Mar Biol 18:681

3. Brown AC, Mclachlan A (1990) Ecology of sandy shores. Elsevier Science Publishers, New York, 328 $\mathrm{p}$

4. Burgess RM, Ho KT, Morrison GE, Chapman G, Denton D (1996) Marine toxicity identification evaluation (TIE). Phase I guidance document. EPA/600/R-96/054. Narragansett, Rhode Island

5. Burton GA, Johnston EL (2010) Assessing contaminated sediments in the context of multiple stressors. Environ Toxicol Chem 29:2625-2643

6. Chapman PM, Wang F, Germano JD, Batley G (2002) Pore water testing and analysis: the good, the bad and the ugly. Mar Pollut Bull 44(5):359-366

7. Cherkashin SA, Blinova NK (2010) Effect of Heavy Metals on Survival of Crustaceans (a Review). Hydrobiological J 46(6):76-87

8. CONAMA (2012) Resolução $n^{\circ} 454$, de 01 de novembro de 2012. Estabelece as diretrizes gerais e os procedimentos referenciais para o gerenciamento do material a ser dragado em águas sob jurisdição nacional. Diário Oficial da União, Brasília, Edição nº 216 de 08/11/2012

9. Day JW (1989) Estuarine ecology. New York, J. Wiley $558 \mathrm{p}$

10. Figuerêdo LP, Nilin J, Queiroz da Silva A, Loureiroc S, Costa-Lotufo LV (2016) Development of a shortterm chronic toxicity test with a tropical mysid. Mar Poll Bull 106:104-108

11. Heijerick DG, Vangheluwe ML, Janssen CR, Dumon G (2000) Selection and use of marine toxicity assays to assess the quality of dredged sediments. In: Gandrass J, Salomons W, Förstner U. (eds.) Workshop on River Sediments and Related Dredged Material in Europe-Scientific Background from the Viewpoints of Chemistry, Ecotoxicology and Regulations. Geesthacht, Germany, GKSS Research Centre, 3-5 April 2000. 30-40

12. Heinis LJ, Highland TL, Mount DR (2004) Method for testing the aquatic toxicity of sediment extracts for use in identifying organic toxicants in sediments. Environ Sci Technol 38(23):6256-6262

13. Hering JG, Morel FMM (1989) Slow coordination reactions in seawater. Geochim Cosmochim Acta 53:611-618

14. Ho KT, Burgess RM (2009) Marine Sediment Toxicity Identification Evaluations (TIEs): History, Principles, Methods, and Future Research. Book Series the Handbook of Environmental Chemistry. Springer Berlin, Volume 5, Part T. pp. 75-95

15. Hockett JR, Mount DR (1996) Use of metal chelating agents to differentiate among sources of acute aquatic toxicity. Env Toxicol Chemistry 15(10):1687-1693 
16. Holleman AF, Wiberg E (2001) Inorganic Chemistry. Academic Press, San Diego

17. Lapota D, Duckworth D, Word JQ (2000) Confounding Factors in Sediment Toxicology. Issue Papers, $1-19$

18. Li H, Zhang J, You J (2018) Diagnosis of complex mixture toxicity in sediments: Application of toxicity identification evaluation (TIE) and effect-directed analysis (EDA). Environ Pollut 237:944954

19. Lussier SM, Gentile JH, Walker J (1985) Acute and chronic effects of heavy metals and cyanide on Mysidopsis bahia (Crustacea: Mysidacea). Aquat Toxicol 7:25-35

20. Manap N, Voulvoulis N (2016) Data analysis for environmental impact of dredging. J Clean Prod 137:394-404

21. Máximo MV, Mottolla LSM, Resgalla C Jr (2008) Sensibilidade do ouriço Arbacia lixula (Equinodermata: Equinoidea) em testes de toxicidade. J Braz Soc Ecotox 3(1):47-52

22. Moreira LB, Castro IBM, Hortellani MA, Sasaki ST, Taniguchi S, Petti MAV, Fillmann G, Sarkis JES, Bícego MC, Costa-Lotufo LV, Abessa DMS (2017) Effects of harbor activities on sediment quality in a semi-arid region in Brazil. Ecotox Environ Safe 135:137-151

23. Moreira LB, Saes RVST, Peres TF, Taniguchi S, Bícego MC, Marins RV, Abessa DMSA (2019) Toxicity of sediments and dredged material from a semi-arid coastal system to marine invertebrates. Ecotoxicol Environ Contam 14(1):79-89

24. NBR/ABNT (2017) 15308 - Aquatic ecotoxicology - Acute toxicity - Test with mysids (Crustacea). p. 20

25. NBR/ABNT (2020) 15350 - Aquatic ecotoxicology - Short-term chronic toxicity - Test method with sea urchin (Echinodermata: Echinoidea). p. 31

26. Nimmo DR, Hamaker TL (1982) Mysids in toxicity testing - a review. Hydrobiologia 93:171-178

27. Resgalla C Jr, Poleza F, Souza RC, Máximo MV, Radetski CM (2012) Evaluation of effectiveness of EDTA and sodium thiosulfate in removing metal toxicity toward sea urchin embryo-larval applying the TIE. Chemosphere 89(1):102-107

28. SAIC - Science Applications International Corporation (2003) Guide for planning and conducting sediment pore water toxicity identification evaluation (TIE) to determine causes of acute toxicity at navy aquatic sites. Naval Facilities Engineering Service Center. User's Guide UG-2052-ENV

29. Sousa ECPM, Zaroni LP, Bergmann Filho TU, Marconato LA, Kirschbaum AA, Gasparro MR (2012) Acute sensitivity to Nitokra sp benthic copepod to potassium dichromate and ammonia chloride. J Braz Soc Ecotoxicol 7(1):75-81

30. Stojak A, Bonnevie NL, Jones DS (2015) Evaluation of metals, metalloids, and ash mixture toxicity using sediment toxicity testing. Integr Environ Assess Manag 11(1):21-31

31. USEPA (1991) Methods for aquatic toxicity identification evaluations. Phase I toxicity characterization procedures. EPA/600/6-91/003. 2 Edition. Washington 
32. USEPA (1996) Marine toxicity identification evaluation (TIE). Phase I Guidance document.

\section{EPA/600/R-96/054}

33. USEPA (2002) Short-term methods for estimating the chronic toxicity of effluents and receiving waters to marine and estuarine organisms. Third Edition - EPA-821-R-02-014

34. USEPA (2007) Sediment toxicity identification evaluation (TIE). Phases I, II and III. Guidance document. EPA/600/R-07/080

35. Verslycke T, Vangheluwe M, Heijerick D, De Schamphelaere K, Van Sprang P, Janssen CR (2003) The toxicity of metal mixtures to the estuarine mysid Neomysis integer (Crustacea: Mysidacea) under changing salinity. Aquat Toxicol 64:307-315

\section{Tables}

Table 1. Values for 96-h lethal concentration ( $\mathrm{LC}_{50}$ and $\left.\mathrm{LC}_{100}\right)$ and confidence interval ( $\left.\mathrm{Cl}-95 \%\right)$ for metal toxicity toward the mysid Mysidopsis juniae test.

\begin{tabular}{|llllllll|}
\hline Metal $\left(\mathrm{mg} \mathrm{L}^{-1}\right)$ & $\mathrm{Hg}$ & $\mathrm{Cd}$ & $\mathrm{Cu}$ & $\mathrm{Cr}$ & $\mathrm{Zn}$ & $\mathrm{Ni}$ & $\mathrm{Pb}$ \\
$\mathrm{LC}_{50}, 96 \mathrm{~h}$ & 0.02 & 0.22 & 0.03 & 4.12 & 0.33 & 0.25 & 1.85 \\
$(\mathrm{Cl})$ & $( \pm 0.001)$ & $( \pm 0.05)$ & $( \pm 0.01)$ & $( \pm 0.33)$ & $( \pm 0.03)$ & $( \pm 0.04)$ & $( \pm 0.41)$ \\
\hline $\mathrm{LC}_{100}, 96 \mathrm{~h}$ & 0.05 & 1.0 & 0.25 & 10.0 & 1.0 & 1.0 & 5.0 \\
\hline
\end{tabular}

Table 2. Comparative results of the toxicity removal capacity of EDTA and sodium thiosulfate for the metals tested in this study and their comparison with the results obtained by Resgalla Jr. et al. (2012).

\begin{tabular}{|c|c|c|c|c|c|c|c|}
\hline & \multirow{3}{*}{\multicolumn{3}{|c|}{$\begin{array}{l}\text { Study by } \\
\text { Resgalla Jr. et al. (2012) } \\
\text { (sea urchin Arbacia lixula) }\end{array}$}} & \multirow{3}{*}{\multicolumn{3}{|c|}{$\begin{array}{l}\text { This study } \\
\text { (mysid Mysidopsis juniae) }\end{array}$}} \\
\hline & & & & & & & \\
\hline & & & & & & & \\
\hline & & \multicolumn{6}{|c|}{ Toxicity removal by EDTA } \\
\hline & & None & Weak & Strong & None & Weak & Strong \\
\hline \multirow[t]{5}{*}{ Toxicity removal by thiosulfate } & Strong & - & - & - & - & - & - \\
\hline & Weak & $\mathrm{Hg}$ & - & - & $\mathrm{Hg}$ & - & - \\
\hline & None & $\mathrm{Cr}$ & - & $\mathrm{Cu}$ & $\mathrm{Cr}$ & $\mathrm{Cd}$ & $\mathrm{Cu}$ \\
\hline & & $\mathrm{Cd}$ & & $\mathrm{Zn}$ & & $\mathrm{Ni}$ & $\mathrm{Zn}$ \\
\hline & & $\mathrm{Ni}$ & & $\mathrm{Pb}$ & & $\mathrm{Pb}$ & \\
\hline
\end{tabular}


Figures
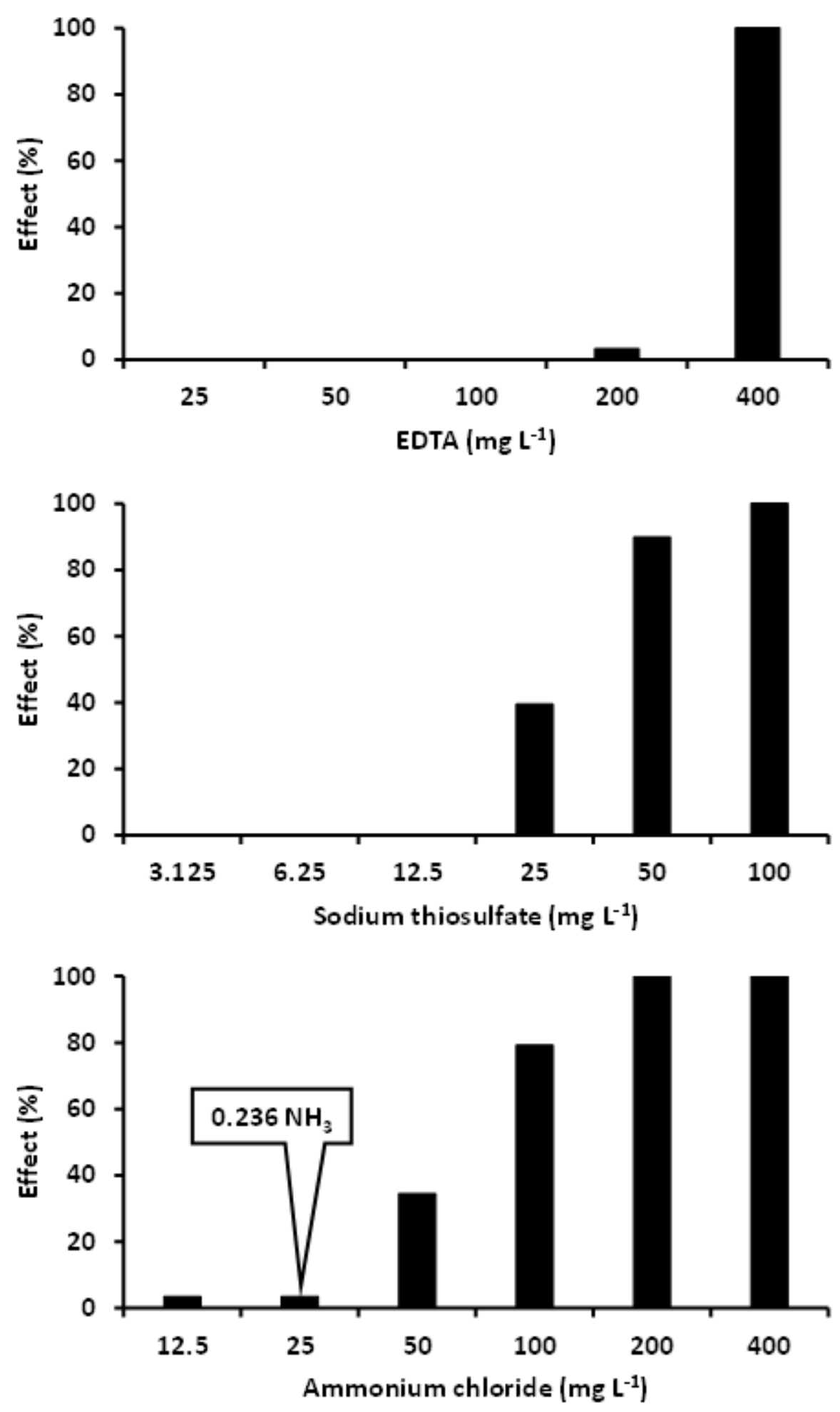

Figure 1

Dose-response ratios observed in the mysid acute toxicity tests in relation to the complexing agents sodium thiosulfate and EDTA, and to ammonium chloride. 

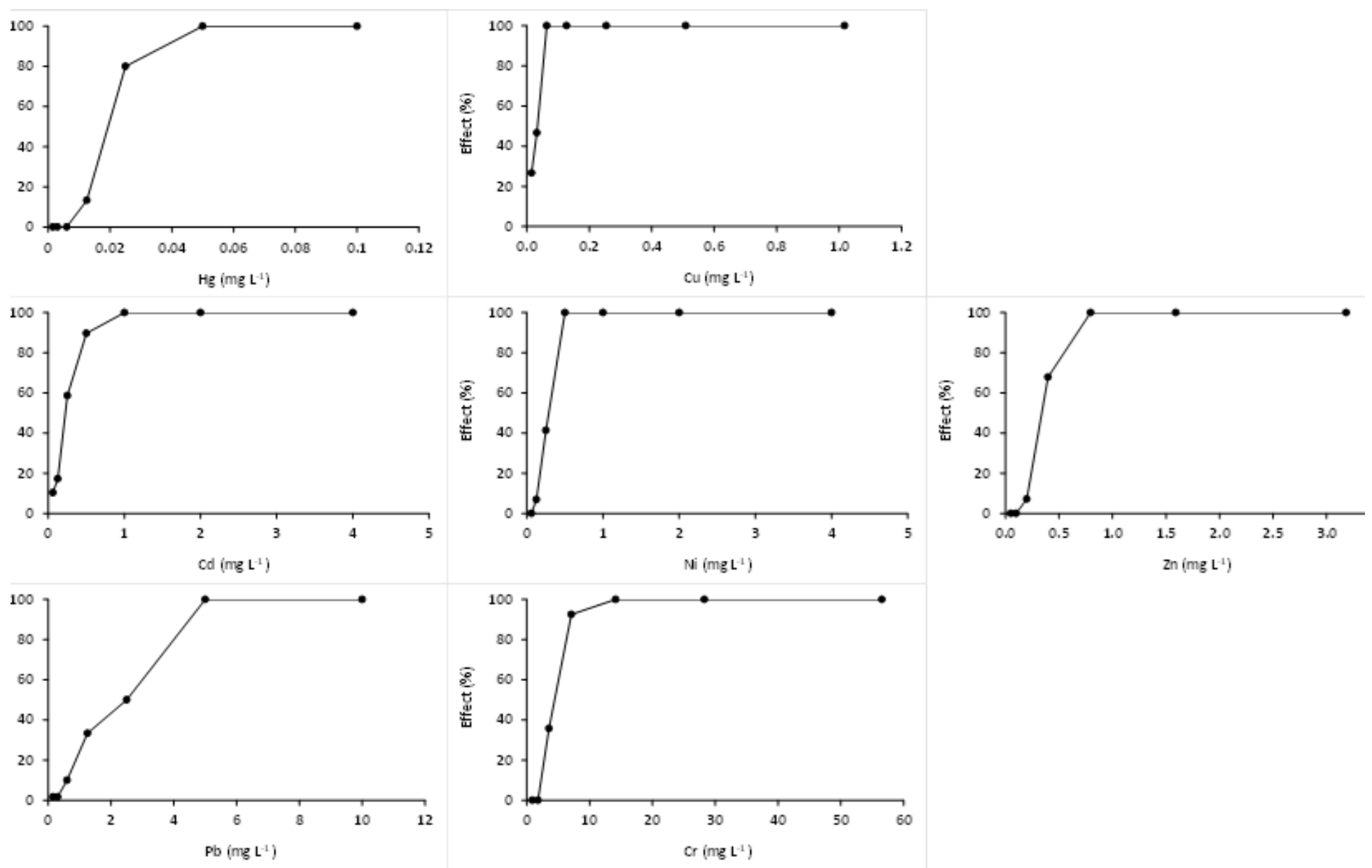

Figure 2

Dose-response ratios observed in the mysid acute toxicity tests in relation to the metals $\mathrm{Hg} 2+, \mathrm{Cd} 2+$, $\mathrm{Cu} 2+, \mathrm{Cr} 6+, \mathrm{Zn} 2+, \mathrm{Ni2}+$ and $\mathrm{Pb} 2+$. 

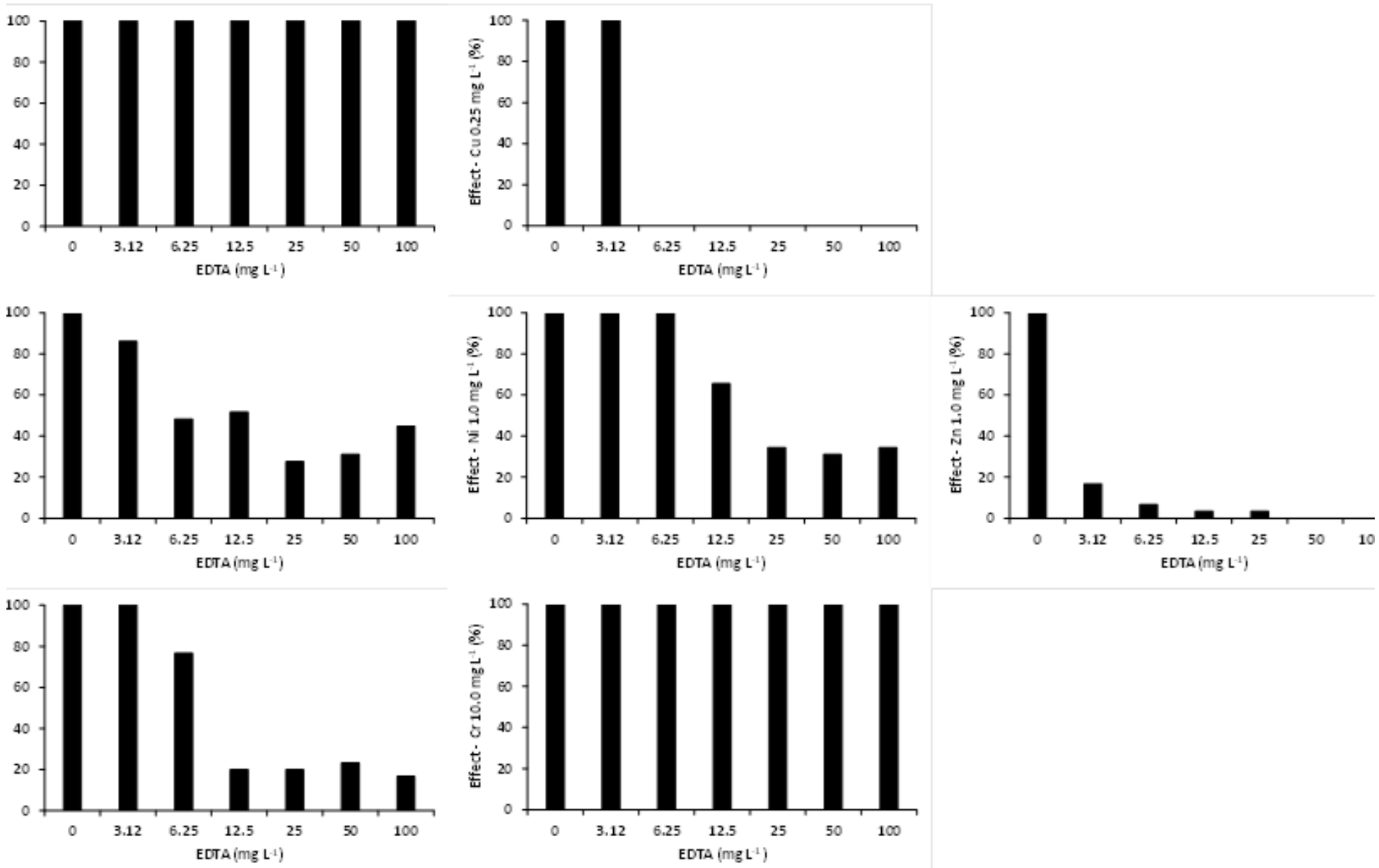

Figure 3

Dose-response ratios observed in the acute toxicity tests with the mysid M. juniae in relation to LC100 (96 h) of the metals associated with the complexing agent EDTA. 

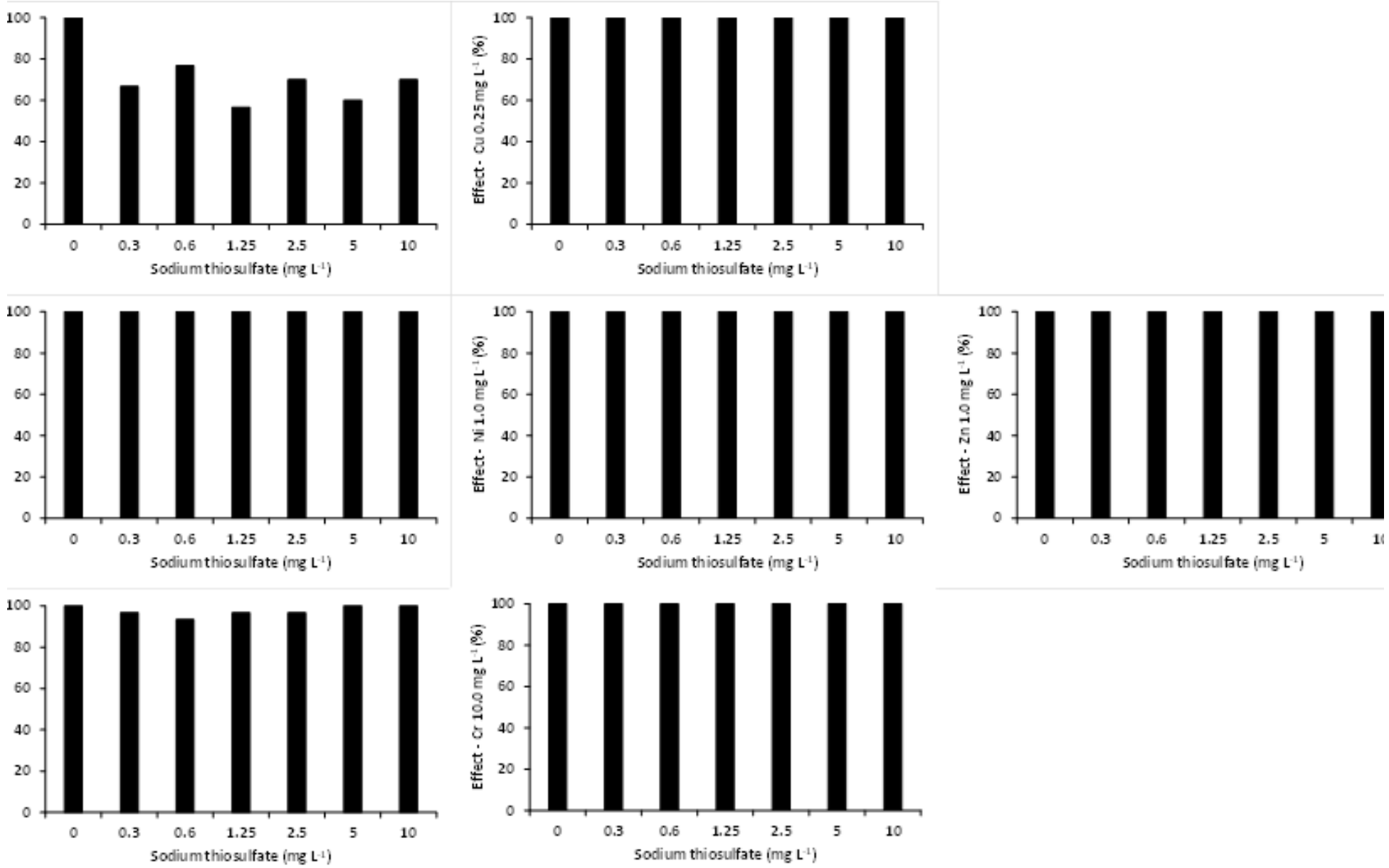

Figure 4

Dose-response ratios observed in the acute toxicity tests with the mysid M. juniae in relation to LC100 (96 h) of the metals associated with the complexing agent sodium thiosulfate. 